\title{
Genetics implicate common mechanisms in autism and schizophrenia: synaptic activity and immunity
}

\author{
Xiaoming Liu, ${ }^{1}$ Zhengwei Li, ${ }^{2}$ Conghai Fan, ${ }^{1}$ Dongli Zhang, ${ }^{1}$ Jiao Chen ${ }^{1}$
}

- Additional material is published online only. To view please visit the journal online http://dx.doi.org/10.1136/ jmedgenet-2016-104487)

${ }^{1}$ Department of Neurology, Xuzhou Children's Hospital, Xuzhou, Jiangsu, China

${ }^{2}$ Department of Pediatric surgery, Xuzhou Children's Hospital, Xuzhou, Jiangsu, China

\section{Correspondence to}

Conghai Fan, Xuzhou Children's Hospital, No. 18, Sudibei Road, Xuzhou, Jiangsu 221002, China; fanconghai020@163.com

Received 5 December 2016 Revised 25 January 2017 Accepted 26 January 2017 Published Online First 17 March 2017
CrossMark

To cite: Liu X, Li Z, Fan C, et al. J Med Genet 2017;54:511-520.

\section{ABSTRACT}

The diagnosis of debilitating psychiatric disorders like autism spectrum disorder (ASD) and schizophrenia $(\mathrm{SCHZ})$ is on the rise. These are severe conditions that lead to social isolation and require lifelong professional care. Improved diagnosis of ASD and SCHZ provides early access to medication and therapy, but the reality is that the mechanisms and the cellular pathology underlying these conditions are mostly unknown at this time. Although both ASD and SCHZ have strong inherited components, genetic risk seems to be distributed in hundreds of variants, each conferring low risk. The poor understanding of the genetics of ASD and SCHZ is a significant hurdle to developing effective treatments for these costly conditions. The recent implementation of next-generation sequencing technologies and the creation of large consortia have started to reveal the genetic bases of ASD and SCHZ. Alterations in gene expression regulation, synaptic architecture and activity and immunity seem to be the main cellular mechanisms contributing to both ASD and $\mathrm{SCHZ}$, a surprising overlap given the distinct phenotypes and onset of these conditions. These diverse pathways seem to converge in aberrant synaptic plasticity and remodelling, which leads to altered connectivity between relevant brain regions. Continuous efforts to understand the genetic basis of ASD and SCHZ will soon lead to significant progress in the mechanistic understanding of these prominent psychiatric disorders and enable the development of disease-modifying therapies for these devastating conditions.

\section{INTRODUCTION}

Recent years have witnessed a dramatic increase in the diagnosis of psychiatric disorders, including autism spectrum disorder (ASD), schizophrenia (SCHZ), attention deficit hyperactivity disorder (ADHD) and intellectual disability (ID), major mood disorders and bipolar disorder. This increase is in part due to more inclusive definitions and increased attention by parents, educators and clinicians. In particular, the rate of autism among infants has reached the level of epidemics with a tremendous social impact. ${ }^{12}$ Historically, advances in understanding the biological bases of psychiatric disorders have progressed at a slower pace than neurological conditions. Some of the factors limiting the research on psychiatric conditions are the constantly evolving definitions, the lack of definitive biomarkers or diagnostic imaging, ${ }^{3}$ under-reporting due to shame or stigma and the unknown aetiology making them intractable for epidemiologists and geneticists. Despite the serious social burden caused by these conditions, the treatments currently available only address the most salient symptoms, but not the underlying problems. Since ASD, SCHZ, ADHD and ID have developmental components, early diagnosis and psychosocial interventions have the potential to partially correct or limit the deficits. However, disease-modifying treatments that specifically target the molecular and cellular pathologies triggering the symptoms will only be realised after reaching a deeper understanding of the mechanisms mediating these psychiatric disturbances. And this understanding will only come from identifying the genetic and environmental factors triggering these conditions. Here, we will review recent advances in the genetics of ASD and SCHZ pointing to common pathogenic mechanisms due to aberrant gene expression, synaptic activity and, surprisingly, immune function. These emerging mechanisms provide renewed hope for the development of targeted and effective treatments in the near future.

One avenue for treating human conditions consists on trying available drugs based on shared phenotypes (symptoms) with other diseases. Although this approach can provide symptomatic relief, it does not treat all the symptoms or the underlying pathology. In extreme cases, the treatment may be partially effective but have deleterious effects, making this approach suboptimal for chronic treatments. The ideal way to treat a disease is to first understand the molecular mechanisms causing the pathology because this knowledge will identify molecular targets at the core of the pathology with the potential to reverse most of the symptoms with the least side effects. In the age of genomics, the best approach to uncover the molecular basis of human disease is to identify the genes whose variants cause the disease (monogenic) or contribute to disease risk (polygenic). Both ASD and SCHZ have strong genetic components (around 50\% heritability) as indicated by twin studies, in which around $89 \%$ of the risk comes from genetics. ${ }^{4-7}$ These observations suggest that a few rare and highly penetrant causative variants explain large fractions of heritability. However, for many years traditional genetic mapping studies and more recent genome-wide association studies (GWAS), which enables scanning entire genomes for variants associated with disease risk, failed to identify statistically significant hits in ASD and SCHZ. This scenario was frustrating for researchers and the affected families because strategies that explained other complex brain conditions did not work in ASD and SCHZ. At the same time, no specific environmental factors proved to be causative for these conditions, thus failing to explain the origin and mechanisms of these prevalent and debilitating conditions. 
The situation changed with the establishment of large-scale international collaborations like the Psychiatric Genomics Consortium (PGC) that pooled many small cohorts to increase the power of prediction. The PGC also developed a Psych Chip at a cost of $\$ 50$ per patient containing 60000 common and rare variants previously implicated in SCHZ that fell short of statistical significance as well as genes within CNVs (including deletions and duplications) of interest. The last few years have yielded dramatic advances in the genetic bases of ASD and SCHZ with the identification of a few rare variants with high penetrance and a number of common variants in key pathways controlling gene expression, synaptic activity and immune function. The potential functional connections between these different pathways in brain development and synaptic function can explain the developmental components of ASD and SCHZ.

\section{ASD pathology}

ASD includes a continuum of conditions that manifest in early childhood characterised by impaired social communication, lack of interest and repetitive behaviours. ${ }^{8}$ Patients with autism often suffer ID, epilepsy, motor problems, ADHD, anxiety, sleep alterations and digestive issues. ${ }^{8}$ Over the last decade, autism has received heightened attention due to the continuous increase in diagnosis (reaching $1 \%$ in children worldwide), vocal advocacy and misguided attention towards vaccines. The distribution of ASD by gender is highly heterogeneous, with recent estimates suggesting that up to 1 in 42 boys and 1 in 189 girls are affected in the USA. ${ }^{9}$ Autism is also part of the clinical presentation of other (syndromic) conditions, including Rett syndrome, fragile $\mathrm{X}$ syndrome, tuberous sclerosis, neurofibromatosis and phosphatase and tensin homologue (PTEN) macrocephaly. These conditions, although highly complex, account for $5 \%-7 \%$ of all autism cases and their known monogenetic origin can contribute to the discovery of the molecular basis underpinning autism (see below).

ASD is proposed to be caused by abnormal brain growth and connectivity; unfortunately, the brains of patients with ASD show no specific morphological abnormalities ${ }^{3}$ or cellular pathology that can support that theory. So far, the mechanisms disturbing neural communication and sensory integration remain to be discovered. Due to the lack of specific knowledge of the pathophysiology of ASD, the only available treatments include behavioural therapy, which works well for some patients and drugs that treat some of the symptoms, like risperidone for the aggressive and repetitive behaviour and aripiprazole to control irritability. However, no therapies treat the social interaction deficits that are at the core of autism, creating a big gap that can be bridged with improved understanding of ASD genetics.

\section{Genetics of ASD}

Twin studies find 60\%-90\% concordance for ASD, supporting a strong genetic component to ASD risk. ${ }^{4-6}$ Overall, heritability is around $50 \%$ with the environment contributing the other $50 \%{ }^{10}$ Despite this strong genetic contribution, identifying genes causative of ASD has been challenging.

One important clue to ASD pathogenesis comes from syndromic conditions that have autism as part of complex syndromes. Several of these conditions are caused by mutations in single genes, including methyl-CpG-binding protein 2 (MECP2) in Rett syndrome, ${ }^{11}$ fragile X mental retardation 1 (FMR1) in fragile X syndrome, ${ }^{12}$ tuberous sclerosis 1 (TSC1) or TSC2 in tuberous sclerosis, ${ }^{13}$ neurofibromin 1 (NF1) in neurofibromatosis ${ }^{14}$ and PTEN in PTEN macrocephaly. ${ }^{15}$ These six monogenetic triggers of autism (among other symptoms) provide direct clues about the molecular basis of ASD. TSC1, TSC2 and PTEN are signalling molecules that regulate cell growth and other activities, and NF1 encodes a Ras inhibitor with pleiotropic activities in the cell. We will describe in more detail the role of MECP2 and FMRP in the regulation of gene expression. In all, altered gene expression and cell signalling can perturb early brain development and cause ASD, but the wide range of substrates for each of these regulatory genes hinders the identification of the specific developmental alterations that lead to ASD. In addition, the contributions of these genes to autism may be confounded with many other developmental abnormalities.

Except for these syndromic ASD genes, recent efforts have identified large numbers of genes (more than 1000) that contribute to ASD risk (reviewed in ref. 10) However, no single gene with strong contribution to autism has been identified so far. The genetic findings suggest that ASD is associated with hundreds of rare variants and around 100 common variants with small effects each. ${ }^{16}{ }^{17}$ These variants are single-nucleotide polymorphisms (SNPs) and CNVs, but few are known to be causative and the genes associated with them remain mostly unknown. Most CNVs are found in a single patient, but three regions (15q11-q13, 16p11 and 22q11) have been found in many cases suggesting the inclusion of one of more relevant genes in those regions. ${ }^{10} 1819$ Patients with ASD also show an increase in de novo variants, including rare mutations with high penetrance, and CNVs compared with the normal population. ${ }^{20}$ Interestingly, some patients carry more than one CNV, supporting a multiple hit model for autism. ${ }^{10}$

The increased frequency of de novo mutations and CNVs in ASD supports a major contribution of a few genes (oligogenic model). But the contribution of de novo mutations to heritability seems to be overestimated. ${ }^{8}$ The picture that emerges so far for ASD supports a polygenic model where the additive effect of several variants causes disease, with the main contribution arising from common variants and a minor contribution coming from rare and de novo variants in combination with environmental factors. ${ }^{8}$ This model is consistent with a complex disorder like ASD with a continuum of phenotypes, where multiple variants add to the risk and severity of the disease. The weakness of this model is the lack of replication of statistically significant variants, suggesting the need to increase sample sizes.

\section{SCHZ pathology}

$\mathrm{SCHZ}$ is a debilitating and heterogeneous psychiatric disturbance characterised by delusions, hallucinations, psychotic episodes, loss of interest, social withdrawal and cognitive impairment. ${ }^{7}$ The first symptoms of SCHZ typically appear in late adolescence or early maturity, although they are preceded by signs suggesting an earlier origin of the disease. Some of the symptoms may be intermittent, with periods of remission, but the combined pathology has a profound social impact, as indicated by the $80 \%-90 \%$ unemployment rates among patients. ${ }^{21}{ }^{22}$ Importantly, patients with SCHZ show abnormal function of multiple organs and metabolism and their life expectancy is reduced by $10-20$ years. ${ }^{23}$ These symptoms are independent of the toxic effects of antipsychotic medication, suicide and poor health, suggesting a systemic disturbance that causes accelerated ageing, ${ }^{24}$ a connection with neurodegenerative diseases worth exploring. In addition, SCHZ symptoms are heterogeneous, overlap with other psychiatric conditions, or are secondary to other diseases or medication, complicating its diagnosis and study, thus delaying research. Current SCHZ treatments include antipsychotic drugs and behavioural therapies, although 
long-term use of antipsychotics causes neurotoxicity and has serious side effects that lead to poor adherence, ${ }^{25}$ revealing a prominent gap in the treatment of SCHZ.

As with ASD, there are no diagnostic tests for SCHZ and no specific brain pathology implicating any particular part of the brain. ${ }^{3}$ However, the cognitive deficits implicate the prefrontal cortex and many brain regions experience subtle, progressive neuronal loss, particularly the temporal lobe, caudate nucleus and thalamus. ${ }^{26}$ However, no brain changes are specific and diagnostic for SCHZ, supporting the complex and heterogeneous pathology of this condition. ${ }^{3}$ Pharmacological studies suggest that aberrant dopamine neurotransmission is implicated in the psychotic symptoms, although these abnormalities are also present in other conditions. ${ }^{27}$ Abnormal glutamate neurotransmission also seems to be implicated in SCHZ, particularly in the cognitive impairment. ${ }^{28}$ The picture emerging from these data suggests diffuse and widespread brain dysfunction due to abnormal activity of dopaminergic and glutamatergic systems, aberrant connectivity possibly implicating interneurons and altered glia function due to inflammation and other stressors. A combination of genetic and environmental factors can perturb critical pathways during brain development leading to abnormal maturation that manifests fully in early adults.

\section{Genetics and epidemiology of SCHZ}

Originally, SCHZ was viewed as an alteration in early brain development (neurodevelopmental theory) that prevented full brain maturation. ${ }^{2930}$ More recently, a two-hit model was proposed to explain the heterogeneity in SCHZ with an early developmental component and a later hit that triggered the symptoms. ${ }^{31} 32$ Currently, a multihit model that combines multiple genes and environmental factors that perturb brain development during key milestones seems to better describe the complexity of SCHZ, ${ }^{33}$ a theory that bears many similarities with ASD.

As with ASD, SCHZ has strong heritability, with as much as $80 \%$ of disease risk according to twin studies, ${ }^{34}$ but genetics alone does not explain all the disease risk. Additional environmental factors seem to contribute to SCHZ risk and, in combination with genetic factors, seem to better explain disease heterogeneity and complexity. A variety of social and environmental factors increase the risk of SCHZ, including social defeat, childhood trauma, social cognition, nutrition, smoking, cannabis use, low IQ, vitamin D deficiency and infection/neuroinflammation affecting the mother during pregnancy (see below). ${ }^{33}$ Each of these conditions likely have small effects, but combined with genetic variants at sensitive neurodevelopmental stages can alter brain development enough to cause SCHZ symptoms in early adulthood.

Recent advances in genetics support the complexity and polygenicity of SCHZ. GWAS have identified SNPs in over 100 common variants with small effects representing hundreds of genes. Note that 50\%-66\% of heritability of SCHZ arises from common variants, indicating their importance. ${ }^{35} 36$ Combinations of these variants are expected to have significant contribution to disease, but studies have not yet confirmed how these genes work together to induce neurodevelopmental deficits. One of the consortia studying SCHZ identified 108 genes associated with SCHZ from GWAS, ${ }^{37}$ a limited number of candidate genes that will allow monographic studies searching for causative mutations. This set of SCHZ loci was enriched in genes expressed in the brain and in immune tissues, which agrees with previous data suggesting critical roles for neural development, synaptic function and immunity in disease risks/mechanisms.
An independent study performed targeted sequencing of 2500 candidate genes and identified mutations in genes implicated in voltage-gated calcium ion channels, cytoskeletal complexes in the postsynaptic density and targets of FMRP, ${ }^{35}$ which narrow the candidate genes and pathways that should be further tested in disease models.

In addition to SNPs, $11 \mathrm{CNV}$ s have a strong contribution to SCHZ, with $4 \%$ of patients carrying a CNV. A $3 \mathrm{Mb}$ deletion at $22 \mathrm{q} 11.2$ is associated with SCHZ in $25 \%$ of the cases and a duplication of this region seems to protect against SCHZ. ${ }^{38}{ }^{39}$ It is unclear whether these $\mathrm{CNV}$ s contain a dose-sensitive gene, where a deletion or a duplication confer significant risk for SCHZ or contain several genes with a cumulative risk. In both cases, their strong contribution makes them highly valuable as we will discuss below. Most CNVs in psychiatric disorders are de novo mutations that are not inherited from the parents, ${ }^{40}$ which is consistent with the decreased life expectancy and fecundity in patients with SCHZ. Exome sequencing recently found that de novo mutations are enriched in postsynaptic genes implicating cytoskeletal and NMDA ( $N$-methyl-D-aspartate) receptor complexes and targets of FMRP. ${ }^{40}$ The pathways disrupted by de novo mutations overlap with the SCHZ genes identified by GWAS and with other sets identified for ASD and ID, supporting a shared pathology in severe psychiatric disorders.

\section{Overlap between ASD and SCHZ}

ASD and SCHZ overlap in some symptoms, like ID, but the core phenotypes and the onset are disease specific. To the naive observer, this would suggest distinct pathogenic mechanisms for ASD and SCHZ and, therefore, the implication of different causative genes and environmental factors. Surprisingly, the dedicated genetic studies of the last few years have revealed significant similarities between ASD and SCHZ, including genetic variants, gene networks and environmental factors. Among the genetic variants, there is a common CNV for both ASD and SCHZ: the $3 \mathrm{Mb} 22 \mathrm{q} 11.2$ region associated with the Phelan-McDermid syndrome. $22 \mathrm{q} 11$ deletions increase the risk for ASD, SCHZ and ID $^{383941}$ and 22q11 duplications also increase the risk for ASD and ID but seem to protect against SCHZ. ${ }^{42}$ Although $\mathrm{CNV}$ s like this contain hundreds of genes, the association of $22 \mathrm{q} 11$ with a developmental disorder and psychiatric conditions is highly suggestive of shared genetic mechanisms.

Despite the strong heritability of both ASD and SCHZ, around $50 \%$ of disease risk is unaccounted for, suggesting the contribution of environmental factors. One of the most significant overlaps between ASD and SCHZ relates to the involvement of chronic inflammation and neuroinflammation in early development, particularly in conditions affecting pregnant women. ${ }^{23}$ Expectant mothers with autoimmune disorders or suffering infections at specific times during gestation have a higher risk of having children with ASD and ID 2445 The presence of autoantibodies from the mom can alter early brain development of the baby, although these antibodies have been detected in the absence of autoimmune disease in the mother. ${ }^{2}$ Moreover, chronic immune changes have also been observed in individuals affected with ASD, implicating autoimmunity and the presence autoantibodies reactive to brain cells, increased cytokines and impaired immune cell response following an immune challenge (reviewed in ref. 2). Moreover, increased levels of cytokines in the brain are proposed to interfere with synaptogenesis. Even the microbiota seems to associate with ASD, suggesting a connection between immune system maturation and brain development (reviewed in ref. 2). Similarly, stressors such as childhood trauma and social 
defeat can cause inflammation and altered neurotransmitter release and contribute to SCHZ. ${ }^{33}$ More importantly, several environmental stressors can activate human endogenous retroviruses (HERV); these HERV proteins and antibodies against them induce neuroinflammation that can be problematic during sensitive stages of development. ${ }^{33}$ In addition, maternal stress and infections also raise the risk for $\mathrm{SCHZ},{ }^{45-47}$ supporting a developmental component in SCHZ. Overall, these genetic and environmental risks support the shared mechanisms in ASD and SCHZ and reveal the impact of altered autoimmunity in brain developmental, particularly during gestation.

\section{Altered gene expression in ASD and SCHZ}

Several genes implicated in the regulation of gene expression are mutated in ASD and SCHZ (table 1). These genes regulate vital cellular activities such as chromatin remodelling, transcription and translation, and the targets of these genes are highly diverse and affect multiple cellular processes. Altered gene expression is particularly critical in neurons because activity-dependent gene expression plays key roles in plasticity and remodelling. The best-studied gene associated with autism is MECP2, which encodes a protein that binds methylated DNA and represses transcription, resulting in the epigenetic control of gene expression. MECP2 is on the X chromosome and its deletion causes Rett syndrome in females, but duplications of MECP2 cause ASD in boys and girls. ${ }^{1148}$ Lack of MECP2 results in de-repressed transcription, whereas excess of MECP2 can perturb activity-dependent gene expression. Another example of syndromic autism is the loss of FMR1 function in fragile X syndrome, which presents with mental retardation and autism. ${ }^{49}$ FMRP is an RNA-binding protein that regulates mRNA shuttling and translation, thus controlling the amounts of mature mRNA that are translated. ${ }^{50}$ Mutations in both MECP2 and FMRP suggest that reduced levels of gene expression or reduced capacity to respond timely to activity-dependent gene expression demands results in altered brain development with severe consequences, including ASD, ID and progressive loss of locomotor skills. ${ }^{10}$ The function of these proteins and the severe defects in early development suggest the involvement of many potential targets, which complicates the identification of specific mechanisms and therapeutic targets.

Mutations in other genes involved in gene expression regulation in patients with ASD, including myocyte-specific enhancer factor 2C (MEF2C), histone deacetylase 4 (HDAC4), chromodomain-helicase-DNA-binding protein 8 (CHD8) and catenin $\beta 1$ (CTNNB1), further support the role of altered gene expression in ASD pathogenesis (reviewed in ref. 10). De novo mutations in MEF2C identified in ASD cause LOF of MEF2C, which is a negative regulator of synapse number. ${ }^{51}$ The increase in synapse density in mice carrying MEF2C LOF mutations supports the role of gene expression regulation in synaptic plasticity and remodelling during brain development. ${ }^{51}$ Building neuronal networks requires the ability to modulate synapse number and strength to adequately respond to stimuli; thus, cellular mechanisms that increase or decrease synapse stability impact the maturation of time-sensitive brain networks. Interestingly, CHD8 is a negative regulator of CTNNB1 and both seem to regulate brain growth. ${ }^{53}$ Animal models expressing abnormal levels of CHD8 or CTNNB1 show changes in brain size, ${ }^{53} 54$ suggesting a role in neuroblast proliferation, differentiation and maturation.

The most interesting development in this area has been the recent report of several LOF mutations in SETD1A (SET domain containing $1 A$ ) in patients with SCHZ, including de novo mutations identified by exome sequencing. ${ }^{55} 56$ SETD1A is the catalytic subunit of a histone $\mathrm{H} 3 \mathrm{~K} 4$ methyltransferase complex (COMPASS) that regulates chromatin structure and gene expression, supporting the role of epigenetic regulation in SCHZ. Patients carrying SETD1A mutations also showed other neurodevelopmental phenotypes, including ID, developmental delay and epilepsy. ${ }^{55}$ De novo mutations in other genes implicated in gene expression regulation, including $R B B P 5, T R R A P$, UBR5, KDM $2 B$ and KDM5C, have been proposed recently, but no replication studies have confirmed their role in SCHZ with a high degree of confidence. Interestingly RBBP5 is another subunit of the COMPASS complex, while two other COMPASS subunits (KMT2A and KMT2C) and a direct interactor with the COMPASS complex (CHD8) harbour mutations in patients with ASD, ${ }^{57} 58$ strengthening the shared mechanisms in ASD and SCHZ.

Overall, alterations in gene expression regulation cause ASD and SCHZ together with other neurodevelopmental and psychiatric disorders, like ID and epilepsy, suggest widespread perturbations in brain development. However, these conditions have no clear disruption of brain anatomy; hence, the defects induced are subtle, involving altered synapse number and strength with the expected perturbations in synaptic plasticity and remodelling. The involvement of chromatin remodelling factors and epigenetic regulators of gene expression suggest the potential misregulation of large numbers of target genes. However, these ASD and SCHZ genes seem to converge in altered synaptic plasticity and remodelling during development. The ability to reshape synaptic function and connections is key for neuronal activities such as learning, but it is particularly critical during fetal development and childhood because of the continuous growth of the brain and the significant demands from new external stimuli. Altering the chromatin landscape or the composition and activity of transcriptional and translational complexes will delay transcriptional responses to developmental and environmental stimuli. The slow building or pruning of synapses may alter critical developmental windows leading to irreparable errors during the maturation of neuronal circuits that can produce symptoms in early childhood (ASD) or early adulthood (SCHZ). Additional validation of causative genes controlling gene expression and modelling in animal models and induced pluripotent stem cells will clarify the molecular mechanisms leading to these psychiatric disturbances.

\section{Altered synaptic activity in ASD and SCHZ}

ASD and SCHZ are neurodevelopmental disorders without obvious morphological brain abnormalities. In the absence of macroscopic alterations, subtle but widespread perturbations at the cellular level have been proposed to underlie both pathologies. Current models suggest that aberrant neuronal connectivity, synaptic plasticity and/or synapse remodelling are at the core of the cellular pathologies of ASD and SCHZ. ${ }^{78}$ In support of the altered neuronal activity, several core symptoms of ASD (anxiety, depression and/or obsessive compulsive disorder) can be treated with selective serotonin reuptake inhibitors (SSRIs). Similarly, the symptomatic treatment of SCHZ includes antipsychotic medications that block dopamine transmission. These treatments indicate a strong role for altered neurotransmission in ASD and SCHZ. Thus, identifying additional mutations in genes implicated in neuronal function and synaptic activity would support a hypothesis based on deficient neurotransmission in ASD and SCHZ. In fact, recent studies have identified numerous candidate genes by GWAS and de novo mutations in synaptic genes in both conditions, although no causative mutation has been identified in this group with high confidence so far. 
Table 1 ASD and SCHZ genes implicated in gene expression regulation

\begin{tabular}{|c|c|c|c|c|}
\hline Gene & Name/protein & Function & Risk/other disease & References \\
\hline \multicolumn{5}{|c|}{ Chromatin remodelling, transcription, translation } \\
\hline MECP2 & Methyl-CpG-binding protein 2 & $\begin{array}{l}\text { Histone methylation, chromatin remodelling, } \\
\text { transcriptional repression }\end{array}$ & $\uparrow A S D+$ Rett syndrome & 11 \\
\hline FMR1 & Fragile $\mathrm{X}$ mental retardation 1/FMRP & mRNA binding, maturation, transport to cytosol & $\uparrow A S D$ + fragile $X$ syndrome & 12 \\
\hline EIF4E & Eukaryotic translation initiation $4 \mathrm{E}$ & $\begin{array}{l}\text { CYFIP1-EIF4E-FMR1 complex mediates translational } \\
\text { repression }\end{array}$ & $\uparrow A S D+$ fragile $X$ syndrome & 3540 \\
\hline CYFIP1 & Cytoplasmic FMRP-interacting protein 1 & $\begin{array}{l}\text { CYFIP1-EIF4E-FMR1 complex mediates translational } \\
\text { repression }\end{array}$ & $\begin{array}{l}\uparrow \mathrm{ASD}+\mathrm{SCHZ}+\text { fragile } \mathrm{X} \\
\text { syndrome }\end{array}$ & 3540 \\
\hline MEF2C & Myocyte-specific enhancer factor 2C & $\begin{array}{l}\text { MEF2 transcription factor family, regulates synapse } \\
\text { number }\end{array}$ & $\uparrow A S D$ in de novo mutations & 77 \\
\hline HDAC4 & Histone deacetylase 4 & $\begin{array}{l}\text { Histone deacetylation, chromatin remodelling, } \\
\text { transcriptional repression }\end{array}$ & ASD & 78 \\
\hline CHD8 & Chromodomain-helicase-DNA-binding protein 8 & $\begin{array}{l}\text { Transcriptional regulator, represses CTNNB1, regulates } \\
\text { brain growth, interacts with COMPASS }\end{array}$ & $\begin{array}{l}\uparrow \text { ASD in de novo mutations + } \\
\text { macrocephaly }\end{array}$ & 5758 \\
\hline CHD7 & Chromodomain-helicase-DNA-binding protein 7 & $\begin{array}{l}\text { Transcriptional regulator, positive regulator of rRNA } \\
\text { biogenesis }\end{array}$ & ASD + CHARGE syndrome & 79 \\
\hline KMT2A & Lysine (K)-specific methyltransferase $2 \mathrm{~A}$ & $\begin{array}{l}\text { Subunit of Histone methyltransferase COMPASS } \\
\text { complex }\end{array}$ & ASD in de novo mutations & 5758 \\
\hline KMT2C & Lysine (K)-specific methyltransferase $2 \mathrm{C}$ & $\begin{array}{l}\text { Subunit of Histone methyltransferase COMPASS } \\
\text { complex }\end{array}$ & ASD in de novo mutations & 5758 \\
\hline SMARCC1,2 & $\begin{array}{l}\text { SWI/SNF-related, matrix-associated, actin- } \\
\text { dependent regulator of chromatin } \mathrm{C} 1 \text { and } 2\end{array}$ & Chromatin remodelling, regulates neurogenesis & ASD variants & 57 \\
\hline SMARCA2 & $\begin{array}{l}\text { SWI/SNF-related, matrix-associated, actin- } \\
\text { dependent regulator of chromatin A2 }\end{array}$ & Chromatin remodelling, regulates neurogenesis & $\mathrm{SCHZ}$ variants & 80 \\
\hline TBR1 & T-box brain 1 & Transcription factor, regulates neurogenesis & $\uparrow A S D$ in de novo mutations & 81 \\
\hline FOXP1 & Forkhead Box P1 & Transcription factor, mTOR signalingfoxp1 & ASD in de novo mutations & 73 \\
\hline CTNNB1 & Catenin $\beta 1$ & $\begin{array}{l}\text { Transcription factor, activates WNT and regulates brain } \\
\text { growth }\end{array}$ & ASD & 5758 \\
\hline EIF4E & Eukaryotic translation initiation factor $4 \mathrm{E}$ & $\begin{array}{l}\text { cap-dependent translation downstream of mTOR. } \\
\text { Regulates other ASD genes with synaptic roles }\end{array}$ & ASD variants & 82 \\
\hline TAF1L & $\begin{array}{l}\text { TAF1 RNA pol II, TATA box binding protein (TBP)- } \\
\text { associated factor }\end{array}$ & RNA pol II-mediated transcription & ASD in de novo mutations & 73 \\
\hline TAF13 & Transcription initiation factor TFIID subunit 13 & RNA pol II-mediated transcription & SCHZ de novo mutations & 40 \\
\hline SETD1A & SET domain containing $1 \mathrm{~A}$ & $\begin{array}{l}\text { Subunit of histone methyltransferase COMPASS } \\
\text { complex }\end{array}$ & $\uparrow \mathrm{SCHZ}$, several mutations & 5583 \\
\hline RBBP5 & Retinoblastoma-binding protein 5 & $\begin{array}{l}\text { Subunit of Histone methyltransferase COMPASS } \\
\text { complex }\end{array}$ & $\mathrm{SCHZ}$ variants & 84 \\
\hline C7orf60 & Probable methyltransferase BTM2 homologue & $\begin{array}{l}\text { Probable S-adenosyl-L-methionine-dependent } \\
\text { methyltransferase }\end{array}$ & SCHZ de novo mutations & 40 \\
\hline TRRAP & $\begin{array}{l}\text { Transformation/transcription domain-associated } \\
\text { protein }\end{array}$ & $\begin{array}{l}\text { Component of the NuA4 histone acetyltransferase } \\
\text { complex }\end{array}$ & $\mathrm{SCHZ}$ variants & 85 \\
\hline UBR5 & E3 ubiquitin-protein ligase & $\begin{array}{l}\text { Promotes accumulation of 'Lys-63'-linked histone } \mathrm{H} 2 \mathrm{~A} \\
\text { and } \mathrm{H} 2 \mathrm{AX} \text { at DNA damage sites }\end{array}$ & $\mathrm{SCHZ}$ variants & 83 \\
\hline KDM2B & Lysine (K)-specific demethylase 2B & Demethylates 'Lys-4' and 'Lys-36' of histone H3 & $\mathrm{SCHZ}$ variants & 83 \\
\hline KDM5C & Lysine (K)-specific demethylase $5 \mathrm{C}$ & demethylates 'Lys-4' of histone H3 & $\mathrm{SCHZ}$ variants & 83 \\
\hline \multicolumn{5}{|l|}{ Signalling } \\
\hline NF-1 & Neurofibromin-1 & mTOR signalling, regulation of cell size & $\uparrow A S D$ + neurofibromatosis & 86 \\
\hline PTEN & Phosphatase and tensin homologue & mTOR signalling, regulation of cell size & $\uparrow$ ASD + PTEN macrocephaly & 87 \\
\hline SYNGAP1 & RAS GTPase-activating protein 1 & mTOR signalling, regulation of cell size & ASD de novo mutations & 3540 \\
\hline TSC2 & Tuberous sclerosis 2 & mTOR signalling, regulation of cell size & $\uparrow A S D+$ tuberous sclerosis & 88 \\
\hline DYRK1A & $\begin{array}{l}\text { Dual-specificity tyrosine phosphorylation regulated } \\
\text { kinase } 1 \mathrm{~A}\end{array}$ & Phosphorylation of actin complexes at synapse & ASD de novo mutations & 89 \\
\hline
\end{tabular}

ASD, autism spectrum disorder; SCHZ, schizophrenia; SWI/SNF, switching/sucrose non-fermenting; FMRP, Fragile X mental retardation protein; mTOR, mammalian target of rapamycin.

Many ASD-risk genes identified in recent efforts encode proteins involved in neuronal activity and synaptic architecture, including neurotransmission by glutamate (GluN2B), gamma-amino butyric acid (GABA) (GABRA3) and glycine (glycine receptor subunit $\alpha 2$ ); neuritogenesis (Contactin 6); cell adhesion molecules that confer neuronal identity (cadherins); neuronal conduction (Contactin-associated protein-like 2); calcium and sodium channels (CACNA1,
SCN1A) and the activity-driven synapse formation regulators neurexin and neuroligin (reviewed in ref. 10) (see online supplementary table 1). In addition to these proteins implicated in cell adhesion and neurotransmission, the structure and function of the presynaptic and postsynaptic domains depend on the activity of scaffolding and cytoskeletal proteins. Three genes of the $\mathrm{SH} 3$ and multiple ankyrin repeat domains protein (SHANK) family are found 
altered in patients with ASD and SHANK3 is included in the $22 \mathrm{q} 12$ deletion that confers high risk for ASD and SCHZ. ${ }^{59}$ SHANKs are scaffolding proteins that interact with glutamate receptors and the actin cytoskeleton and LOF of SHANK reduces the accumulation of actin in synapses, which alters axonal growth and synapses maturation. ${ }^{60}$ Mice harbouring mutations in Shank1, Shank2 or Shank3 present autistic-like phenotypes (self-injury, anxiety, repetitive behaviours) and decreases social interaction. ${ }^{51-66}$ These may be the most faithful genetic models of pure ASD described so far, indicating that the structural instability of the synapse is a key contributor to ASD.

As in ASD, many SCHZ-risk genes identified by GWAS are implicated in synaptic activity, including several involved in glutamate neurotransmission as well as several voltage-gated calcium channel subunits (same channel implicated in ASD, but different subunits) (see online supplementary table 1). ${ }^{67}$ Exome sequencing also identified de novo mutations enriched in the NMDA receptor complex and proteins that interact with ARC (activity-regulated cytoskeleton-associated protein) and DLG4 (Disc-large 4). ${ }^{40}$ Revealingly, several studies and a meta-analysis have confirmed variants associated with Dopamine receptor 2 $(D R D 2)$, including a deletion in its promoter that reduces DRD2 expression. ${ }^{56}$ DRD2 is the target of anti-psychotic medications prescribed to patients with SCHZ and ASD, suggesting a mechanism linking symptoms, pharmacology and genetics. However, the contribution of each polymorphism to SCHZ risk is small and more studies will need to uncover causative DRD2 mutations or combinations with other risk variants that significantly increase the risk of SCHZ.

Overall, defects in both excitatory (glutamatergic, dopaminergic) and inhibitory (GABAergic) neurotransmission contribute to ASD and SCHZ, suggesting alterations in the excitation/ inhibition balance. ${ }^{8}$ This perturbation may have developmental (cell identity, connectivity) and/or physiological (plasticity and remodelling) bases.

\section{Immune system perturbations in ASD and SCHZ}

Evidence has gradually accumulated for a contribution of immune dysregulation to ASD, SCHZ and other psychiatric disorders. This connection led to the myth that vaccines given to infants cause ASD, a claim that has been debunked in numerous studies after putting many children at risk of preventable diseases. ${ }^{68}$ The innate immune system is designed to detect and respond to environmental threats, while the adaptive immune system prepares against future attacks. These peripheral immune cells are not expected to enter the brain; excess of immune cells and their products (antibodies and cytokines) can affect brain development and function, and in some cases have harmful effects. ${ }^{2}$ In addition to the exogenous factors linking ASD and SCHZ with immune activation listed above, recent genetic discoveries further support the contribution of the immune system.

The major histocompatibility complex (MHC) contains one of the major regions conferring risk for ASD and SCHZ. The 3.6 Mb MHC contains many complex loci with different copy numbers that makes its analysis particularly challenging. The MHC produces several human leucocyte antigen (HLA) and complement proteins critical for adaptive immunity. Recent efforts identified MHC variants conferring high risk for ASD and causative mutations for SCHZ. Among these, the HLA-A1 haplotype confers high risk for ASD and alleles for HLA-DRB1 combined with autoimmune disorders increase the risk for ASD ${ }^{69}$ More revealing are deficiencies in the MHCIII region affecting a complement gene, C4B. ${ }^{70}$ Loss of complement function is expected to increase autoimmune responses through the production of autoantibodies with harmful consequences. In addition, mutations in members of the IL-1 cytokine receptor family are associated to ASD. Exome sequence has identified synonymous SNPs in the IL-1 $\beta$ decoy receptor IL-1 type 2 (IL-1R2), ${ }^{72} 73$ although the functional consequences of this variant are not known at this time. Mutations and CNV causing LOF in IL-1 receptor accessory protein-like 1 (IL-1RAPL1) are also linked to ASD and ID, ${ }^{74} 75$ indicating the convergence of several psychiatric disorders in the immune system (table 2). Although very revealing, all these MHC variants still need to be confirmed for causality of ASD.

The strongest genetic association for SCHZ by far resides in the $\mathrm{MHC}$ locus and the SCHZ-related variants accumulate throughout the complex. However, the accumulation of variants in the region containing the $C 4$ gene made it a candidate for directed studies. Human $C 4$ encodes two genes, $C 4 A$ and $C 4 B$, each has multiple copies with long and short isoforms depending on the integration of a HERV. CNV and HERV variant suggested a potential role for significant changes in the expression levels of $\mathrm{C} 4 \mathrm{~A}$ and $\mathrm{C} 4 \mathrm{~B}$. A report published this year found a strong correlation between $\mathrm{SCHZ}$ variants and elevated levels of $C 4 A,{ }^{76}$ suggesting a potential mechanistic link to disease pathogenesis. Apparently, elevated activity of C4A can interfere with neuronal maturation and circuit formation. $\mathrm{C} 4$ is known to activate $\mathrm{C} 3$, which binds to receptors in synapses and regulates pruning by microglia during development and is required for synaptic remodelling later on. Experiments in mice support this hypothesis because $C 4$ mutant mice show low levels of C3 in synapses and reduced pruning. ${ }^{76}$ Thus, deficient synaptic pruning due to high levels of $\mathrm{C} 4 \mathrm{~A}$ perturb brain development, maturation and plasticity, which can explain the strong genetic connection between SCHZ and the MHC. Interestingly, while high $\mathrm{C} 4 \mathrm{~A}$ is linked to $\mathrm{SCHZ}$, low $\mathrm{C} 4 \mathrm{~B}$ expression is linked to ASD, intimately connecting these complex psychiatric conditions at the genetic and mechanistic levels. This overlap, hence, supports the idea that alterations of the immune system during sensitive developmental stages have prominent effects in early brain development, resulting in the dramatic manifestations of ASD and SCHZ.

\section{Concluding remarks}

The strong genetic component of ASD and SCHZ was well known for some time, but only recent collaborative efforts using cutting-edge sequencing technology have successfully identified candidate loci and causative genes leading to emerging mechanisms for these severe psychiatric conditions. Although large numbers of candidate genes have been identified so far by GWAS, the relevance for most genes is still unclear lacking replication studies, causative mutations or animal models that demonstrate causality. GWAS typically identify non-coding loci with potential function in the regulation of distant genes. Thus, the path form GWAS loci to causative gene is typically long and leads to many dead ends and frustration. But the picture described here indicates strong contributions of the cellular machineries regulating gene expression, synaptic architecture and activity and immunity. The implication of genes involved in maintaining the synaptic architecture and activity, including cytoskeletal proteins, neurotransmitter receptors and activity-dependent pathways, strongly support abnormal neuronal connectivity and synaptic activity as the cellular basis of ASD and SCHZ. These mechanisms are consistent with the absence of macroscopic changes in the brain of patients, suggesting instead the contribution of diffuse perturbations at the cellular 
Table 2 ASD and SCHZ genes implicated in immunity

\begin{tabular}{|c|c|c|c|c|}
\hline Gene & Name & Function & Risk/other & References \\
\hline$C 4 B$ & C4-B & Convertase, complement cascade protein; synaptic pruning & $\mathrm{ASD}+\mathrm{SCHZ}$ & 70 \\
\hline C4A & C4-A & Convertase, complement cascade protein; synaptic pruning & SCHZ high C4A/C4B ratio & 76 \\
\hline C15 & C1s subcomponent & $\begin{array}{l}\text { Serine protease, the first component of the classical pathway of the } \\
\text { complement system }\end{array}$ & ASD variants & 90 \\
\hline CD99L2 & CD99 antigen-like protein 2 & Homophilic adhesion may not be required for cell adhesion & ASD variants & 91 \\
\hline JARID2 & Protein Jumonji & Regulator of histone methyltransferase complexes, transcriptional repressor & ASD variants & 91 \\
\hline MIF & $\begin{array}{l}\text { Macrophage migration inhibitory } \\
\text { factor }\end{array}$ & $\begin{array}{l}\text { Proinflammatory cytokine that regulates innate immune response to bacterial } \\
\text { pathogens }\end{array}$ & ASD variants & 93 \\
\hline$P R K C B$ & Protein kinase $\mathrm{C}$ beta type & Mediates activation of the canonical NF-kappa-B pathway & ASD variants & 93 \\
\hline HLA-A2 & $\begin{array}{l}\text { HLA class I histocompatibility } \\
\text { antigen, A-2 alpha chain }\end{array}$ & $\begin{array}{l}\text { presentation of foreign antigens to the immune system. Negatively regulates } \\
\text { synapse formation and plasticity in the developing brain }\end{array}$ & ASD variants & 94 \\
\hline IL1R2 & IL-1 receptor type 2 & $\begin{array}{l}\text { Decoy receptor by competitive binding to IL1B and prevents binding to IL1R1. } \\
\text { Regulation of immune response }\end{array}$ & ASD mutation & 73 \\
\hline CD14 & $\begin{array}{l}\text { Monocyte differentiation antigen } \\
\text { CD14 }\end{array}$ & Mediates innate immune response to bacterial lipopolysaccharide & SCHZ de novo mutations & 67 \\
\hline MUC6 & Mucin-6 & Cytoprotection of epithelial surfaces, antibacterial & SCHZ de novo mutations & 40 \\
\hline NLRC5 & Protein NLRC5 & $\begin{array}{l}\text { Regulator of NF-kappa-B and type-I interferon pathways. homeostatic } \\
\text { control of innate immunity and in antiviral defense }\end{array}$ & SCHZ de novo mutations & 40 \\
\hline CCHCR1 & $\begin{array}{l}\text { Coiled-coil alpha-helical rod } \\
\text { protein } 1\end{array}$ & MHC locus, involved in keranocyte proliferation & SCHZ mutation & 35 \\
\hline
\end{tabular}

ASD, autism spectrum disorder; HLA, human leucocyte antigen; IL, interleukin; MHC, major histocompatibility complex; NF, nuclear factor; SCHZ, schizophrenia.

(synaptic) level. These findings agree with the therapeutic benefits of SSRIs in ASD and SCHZ and with the potential role of DRD2 variants in SCHZ, although the causative link has not been demonstrated, so far. In addition, genetic variants identified in ASD and SCHZ together with the well-known function of MECP2 and FMR1 in syndromic autism support the key role of gene expression misregulation (both upregulation and downregulation) in perturbing brain development and the tight regulation of synaptic activity, plasticity and remodelling. These developmental perturbations can be partially compensated until stimulatory demands following birth and environmental factors like maternal infections, neuroinflammation and other immune reactions trigger the symptoms. The most surprising revelation of the genetic studies is the connection with the immune system, which was already suspected due to epidemiological studies and the mapping of genetic variants in the MHC locus. But perturbations in the $\mathrm{C} 4$ locus in patients with both ASD and SCHZ put the immune system front and centre in the pathogenesis of these conditions. Remarkably, C4B is downregulated in ASD and C4A is upregulated in $\mathrm{SCHZ}$, suggesting that altering the balance between the two $\mathrm{C} 4$ isoforms has dramatic consequences in neuronal development, particularly in synaptic pruning.

As discussed above, these advances in understanding the cellular and molecular basis of psychiatric pathologies will provide a rational approach to therapeutics. In simple, monogenetic diseases, the obvious therapeutic target would be the mutant gene, because correcting the deleterious consequences of the mutation should eliminate all the symptoms. Alternatively, downstream factors mediating the phenotypes are the obvious targets for therapeutics. In the case of ASD, SCHZ and other polygenic disorders, identifying the targets is more complex since different genetic variants and environmental factors can combine to trigger pathogenesis. In this situation, personalised genomics can help evaluate the triggers in each individual to tailor the available treatments. When no obvious mutations are detected, understanding that all the risk factors converge in altered connectivity and synaptic activity can lead to the development of drugs that specifically correct these deficits at the transcriptional or synaptic levels. Overall, the advances in the genetics of ASD and SCHZ in recent years are exciting and provide strong molecular basis to focus on specific mechanism, particularly uncontrolled autoimmunity. However, given the heterogeneity and complexity of these conditions, it will take a significant effort to develop new and effective drugs that can treat specifically the perturbations of ASD and SCHZ. In the meantime, understanding the environmental factors contributing to the risk of ASD and SCHZ (an effort that can be substantially aided by understanding the genetics) should reduce the number of cases and their severity, while earlier and more accurate diagnosis will exploit the benefits of behavioural therapy, particularly in ASD.

Acknowledgements The authors are thankful for the secretarial assistance and for all the suggestions from friends and collaborators for improving the manuscript. Xiaoming Liu and Zhengwei Li contributed equally to this article.

Contributors CF conceived this review; XL, ZL, DZ, JC and CF contributed to drafting the article, revising it critically for important intellectual content and approved the final version submitted to the journal. $\mathrm{XL}$ as the senior author is responsible for the final content and guarantor.

Competing interests None declared.

Provenance and peer review Not commissioned; externally peer reviewed.

(c) Article author(s) (or their employer(s) unless otherwise stated in the text of the article) 2017. All rights reserved. No commercial use is permitted unless otherwise expressly granted. 


\section{REFERENCES}

1 Christensen DL, Baio J, Braun KVN, Bilder D, Charles J, Constantino JN, Daniels J, Durkin MS, Fitzgerald RT, Kurzius-Spencer M, Lee L-C, Pettygrove S, Robinson C, Schulz E, Wells C, Wingate MS, Zahorodny W, Yeargin-Allsopp M. Prevalence and characteristics of autism spectrum disorder among children aged 8 years-Autism and Developmental Disabilities Monitoring Network, 11 Sites, United States, 2012. MMWR Surveill Summ 2016;65:1-23.

2 Estes ML, McAllister AK. Immune mediators in the brain and peripheral tissues in autism spectrum disorder. Nat Rev Neurosci 2015;16:469-86

3 Abi-Dargham A, Horga G. The search for imaging biomarkers in psychiatric disorders. Nat Med 2016;22:1248-55.

4 Hallmayer J, Cleveland S, Torres A, Phillips J, Cohen B, Torigoe T, Miller J, Fedele A, Collins J, Smith K, Lotspeich L, Croen LA, Ozonoff S, Lajonchere C, Grether JK, Risch N. Genetic heritability and shared environmental factors among twin pairs with autism. Arch Gen Psychiatry 2011;68:1095-102.

5 Ronald A, Hoekstra RA. Autism spectrum disorders and autistic traits: a decade of new twin studies. American J Med Genet Neuropsychiat Genet 2011;156:255-74.

6 Sandin S, Lichtenstein P, Kuja-Halkola R, Larsson H, Hultman CM, Reichenberg A. The familial risk of autism. JAMA 2014;311:1770-7.

7 Owen MJ, Sawa A, Mortensen PB. Schizophrenia. Lancet 2016;388:86-97.

8 de la Torre-Ubieta L, Won H, Stein JL, Geschwind DH. Advancing the understanding of autism disease mechanisms through genetics. Nat Med 2016;22:345-61.

9 Surveillance D. Prevalence of autism spectrum disorder among children aged 8 years - autism and developmental disabilities monitoring network, 11 sites, United States, 2010. MMWR Surveill Summ 2014;63:1-21.

10 Bourgeron T. From the genetic architecture to synaptic plasticity in autism spectrum disorder. Nat Rev Neurosci 2015;16:551-63.

11 Amir RE, Van den Veyver IB, Wan M, Tran CQ, Francke U, Zoghbi HY. Rett syndrome is caused by mutations in X-linked MECP2, encoding methyl-CpG-binding protein 2. Nat Genet 1999;23:185-8.

12 Verkerk AJ, Pieretti M, Sutcliffe JS, Fu YH, Kuhl DP, Pizzuti A, Reiner O, Richards S, Victoria MF, Zhang FP. Identification of a gene (FMR-1) containing a CGG repeat coincident with a breakpoint cluster region exhibiting length variation in fragile $X$ syndrome. Cell 1991;65:905-14.

13 Magri L, Cambiaghi M, Cominelli M, Alfaro-Cervello C, Cursi M, Pala M, Bulfone A, Garcia-Verdugo JM, Leocani L, Minicucci F, Poliani PL, Galli R. Sustained activation of mTOR pathway in embryonic neural stem cells leads to development of tuberous sclerosis complex-associated lesions. Cell Stem Cell 2011;9:447-62.

14 Védrine SM, Vourc'h P, Tabagh R, Mignon L, Höfflin S, Cherpi-Antar C, Mbarek O, Paubel A, Moraine C, Raynaud M, Andres CR. A functional tetranucleotide (AAAT) polymorphism in an alu element in the NF1 gene is associated with mental retardation. Neurosci Lett 2011:491:118-21.

15 Butler MG, Dasouki MJ, Zhou XP, Talebizadeh Z, Brown M, Takahashi TN, Miles JH, Wang $\mathrm{CH}$, Stratton R, Pilarski R, Eng C. Subset of individuals with autism spectrum disorders and extreme macrocephaly associated with germline PTEN tumour suppressor gene mutations. J Med Genet 2005:42:318-21.

16 Gaugler T, Klei L, Sanders SJ, Bodea CA, Goldberg AP, Lee AB, Mahajan M, Manaa D, Pawitan Y, Reichert J, Ripke S, Sandin S, Sklar P, Svantesson O, Reichenberg A, Hultman CM, Devlin B, Roeder K, Buxbaum JD. Most genetic risk for autism resides with common variation. Nat Genet 2014;46:881-5.

17 Sanders SJ, He X, Willsey AJ, Ercan-Sencicek AG, Samocha KE, Cicek AE, Murtha MT, Bal VH, Bishop SL, Dong S, Goldberg AP, Jinlu C, Keaney JF, Klei L, Mandell JD, Moreno-De-Luca D, Poultney CS, Robinson EB, Smith L, Solli-Nowlan T, Su MY, Teran NA, Walker MF, Werling DM, Beaudet AL, Cantor RM, Fombonne E, Geschwind DH, Grice DE, Lord C, Lowe JK, Mane SM, Martin DM, Morrow EM, Talkowski ME, Sutcliffe JS, Walsh CA, Yu TW, Ledbetter DH, Martin CL, Cook EH, Buxbaum JD, Daly MJ, Devlin B, Roeder K, State MW. Autism Sequencing Consortium. Insights into autism spectrum disorder genomic architecture and biology from 71 risk loci. Neuron 2015:87:1215-33

18 Sanders SJ, Ercan-Sencicek AG, Hus V, Luo R, Murtha MT, Moreno-De-Luca D, Chu SH, Moreau MP, Gupta AR, Thomson SA, Mason CE, Bilguvar K, Celestino-Soper PB, Choi M, Crawford EL, Davis L, Wright NR, Dhodapkar RM, DiCola M, DiLullo NM, Fernandez TV, Fielding-Singh V, Fishman DO, Frahm S, Garagaloyan R, Goh GS, Kammela S, Klei L, Lowe JK, Lund SC, McGrew AD, Meyer KA, Moffat WJ, Murdoch JD, O’Roak BJ, Ober GT, Pottenger RS, Raubeson MJ, Song Y, Wang Q, Yaspan BL, Yu TW, Yurkiewicz IR, Beaudet AL, Cantor RM, Curland M, Grice DE, Günel M, Lifton RP, Mane SM, Martin DM, Shaw CA, Sheldon M, Tischfield JA, Walsh CA, Morrow EM, Ledbetter DH, Fombonne E, Lord C, Martin CL, Brooks Al, Sutcliffe JS, Cook EH, Geschwind D, Roeder K, Devlin B, State MW. Multiple recurrent de novo CNVs, including duplications of the $7 q 11.23$ Williams syndrome region, are strongly associated with autism. Neuron 2011;70:863-85.

19 Pinto D, Delaby E, Merico D, Barbosa M, Merikangas A, Klei L, Thiruvahindrapuram B, Xu X, Ziman R, Wang Z, Vorstman JA, Thompson A, Regan R, Pilorge M, Pellecchia G, Pagnamenta AT, Oliveira B, Marshall CR, Magalhaes TR, Lowe JK, Howe JL, Griswold AJ, Gilbert J, Duketis E, Dombroski BA, De Jonge MV, Cuccaro M, Crawford EL, Correia CT, Conroy J, Conceição IC, Chiocchetti AG, Casey JP, Cai G, Cabrol C, Bolshakova N, Bacchelli E, Anney R, Gallinger S, Cotterchio M, Casey G, Zwaigenbaum L, Wittemeyer
K, Wing K, Wallace S, van Engeland H, Tryfon A, Thomson S, Soorya L, Rogé B, Roberts W, Poustka F, Mouga S, Minshew N, Mclnnes LA, McGrew SG, Lord C, Leboyer M, Le Couteur AS, Kolevzon A, Jiménez González P, Jacob S, Holt R, Guter S, Green J, Green A, Gillberg C, Fernandez BA, Duque F, Delorme R, Dawson G, Chaste P, Café C, Brennan S, Bourgeron T, Bolton PF, Bölte S, Bernier R, Baird G, Bailey AJ, Anagnostou E, Almeida J, Wijsman EM, Vieland VJ, Vicente AM, Schellenberg GD, Pericak-Vance M, Paterson AD, Parr JR, Oliveira G, Nurnberger JI, Monaco AP, Maestrini E, Klauck SM, Hakonarson $\mathrm{H}$, Haines JL, Geschwind DH, Freitag CM, Folstein SE, Ennis S, Coon H, Battaglia A, Szatmari P, Sutcliffe JS, Hallmayer J, Gill M, Cook EH, Buxbaum JD, Devlin B, Gallagher L, Betancur C, Scherer SW. Convergence of genes and cellular pathways dysregulated in autism spectrum disorders. Am J Hum Genet 2014;94:677-94.

20 Ronemus $M$, lossifov I, Levy D, Wigler M. The role of de novo mutations in the genetics of autism spectrum disorders. Nat Rev Genet 2014;15:133-41.

21 Kooyman I, Dean K, Harvey S, Walsh E. Outcomes of public concern in schizophrenia. Br J Psychiatry 2007;191:s29-36.

22 Marwaha S, Johnson S. Schizophrenia and employment - a review. Soc Psychiatry Psychiatr Epidemiol 2004;39:337-49.

23 Chesney E, Goodwin GM, Fazel S. Risks of all-cause and suicide mortality in mental disorders: a meta-review. World Psychiatry 2014;13:153-60.

24 Anthes E. Ageing: live faster, die younger. Nature 2014;508:S16-17

25 Leucht S, Tardy M, Komossa K, Heres S, Kissling W, Salanti G, Davis JM. Antipsychotic drugs versus placebo for relapse prevention in schizophrenia: a systematic review and meta-analysis. Lancet 2012;379:2063-71.

26 Fusar-Poli P, Smieskova R, Kempton MJ, Ho BC, Andreasen NC, Borgwardt S. Progressive brain changes in schizophrenia related to antipsychotic treatment? A meta-analysis of longitudinal MRI studies. Neurosci Biobehav Rev 2013;37:1680-91.

27 Howes OD, Murray RM. Schizophrenia: an integrated sociodevelopmental-cognitive model. Lancet 2014;383:1677-87.

28 Moghaddam B, Javitt D. From revolution to evolution: the glutamate hypothesis of schizophrenia and its implication for treatment. Neuropsychopharmacology 2012;37:4-15.

29 Murray RM, Lewis SW. Is schizophrenia a neurodevelopmental disorder? Br Med J 1987:295:681-2.

30 Weinberger DR. Implications of normal brain development for the pathogenesis of schizophrenia. Arch Gen Psychiatry 1987:44:660-9.

31 Gogtay N, Vyas NS, Testa R, Wood SJ, Pantelis C. Age of onset of schizophrenia: perspectives from structural neuroimaging studies. Schizophr Bull 2011;37:504-13.

32 Pantelis C, Yucel M, Wood SJ, Velakoulis D, Sun D, Berger G, Stuart GW, Yung A, Phillips L, McGorry PD. Structural brain imaging evidence for multiple pathological processes at different stages of brain development in schizophrenia. Schizophr Bull 2005;31:672-96.

33 Davis J, Eyre H, Jacka FN, Dodd S, Dean O, McEwen S, Debnath M, McGrath J, Maes M, Amminger P, McGorry PD, Pantelis C, Berk M. A review of vulnerability and risks for schizophrenia: beyond the two hit hypothesis. Neurosci Biobehav Rev 2016;65:185-94.

34 Polderman TJC, Benyamin B, de Leeuw CA, Sullivan PF, van Bochoven A, Visscher PM, Posthuma D. Meta-analysis of the heritability of human traits based on fifty years of twin studies. Nat Genet 2015:47:702-9.

35 Purcell SM, Moran JL, Fromer M, Ruderfer D, Solovieff N, Roussos P, O'Dushlaine C, Chambert K, Bergen SE, Kähler A, Duncan L, Stahl E, Genovese G, Fernández E, Collins MO, Komiyama NH, Choudhary JS, Magnusson PK, Banks E, Shakir K, Garimella K, Fennell T, DePristo M, Grant SG, Haggarty SJ, Gabriel S, Scolnick EM, Lander ES, Hultman CM, Sullivan PF, McCarroll SA, Sklar P. A polygenic burden of rare disruptive mutations in schizophrenia. Nature 2014;506:185-90.

36 Ripke S, O'Dushlaine C, Chambert K, Moran JL, Kähler AK, Akterin S, Bergen SE, Collins AL, Crowley JJ, Fromer M, Kim Y, Lee SH, Magnusson PK, Sanchez N, Stahl EA, Williams S, Wray NR, Xia K, Bettella F, Borglum AD, Bulik-Sullivan BK, Cormican P, Craddock N, de Leeuw C, Durmishi N, Gill M, Golimbet V, Hamshere ML, Holmans P, Hougaard DM, Kendler KS, Lin K, Morris DW, Mors O, Mortensen PB, Neale BM, O'Neill FA, Owen MJ, Milovancevic MP, Posthuma D, Powell J, Richards AL, Riley BP, Ruderfer D, Rujescu D, Sigurdsson E, Silagadze T, Smit AB, Stefansson H, Steinberg S, Suvisaari J, Tosato S, Verhage M, Walters JT, Levinson DF, Gejman PV, Kendler KS, Laurent C, Mowry BJ, O'Donovan MC, Owen MJ, Pulver AE, Riley BP, Schwab SG, Wildenauer DB, Dudbridge F, Holmans P, Shi J, Albus M, Alexander M, Campion D, Cohen D, Dikeos D, Duan J, Eichhammer P, Godard S, Hansen M, Lerer FB, Liang KY, Maier W, Mallet J, Nertney DA, Nestadt G, Norton N, O'Neill FA, Papadimitriou GN, Ribble R, Sanders AR, Silverman JM, Walsh D, Williams NM, Wormley B, Arranz MJ, Bakker S, Bender S, Bramon E, Collier D, Crespo-Facorro B, Hall J, lyegbe C, Jablensky A, Kahn RS, Kalaydjieva L, Lawrie S, Lewis CM, Lin K, Linszen DH, Mata I, McIntosh A, Murray RM, Ophoff RA, Powell J, Rujescu D, Van Os J, Walshe M, Weisbrod M, Wiersma D, Donnelly P, Barroso I, Blackwell JM, Bramon E, Brown MA, Casas JP Corvin AP, Deloukas P, Duncanson A, Jankowski J, Markus HS, Mathew CG, Palmer CN, Plomin R, Rautanen A, Sawcer SJ, Trembath RC, Viswanathan AC, Wood NW, Spencer CC, Band G, Bellenguez C, Freeman C, Hellenthal G, Giannoulatou E, Pirinen M, Pearson RD, Strange A, Su Z, Vukcevic D, Donnelly P, Langford C, Hunt SE, Edkins S, Gwilliam R, Blackburn H, Bumpstead SJ, Dronov S, Gillman M, Gray E, Hammond N, Jayakumar A, McCann OT, Liddle J, Potter SC, Ravindrarajah R, Ricketts M, TashakkoriGhanbaria A, Waller MJ, Weston P, Widaa S, Whittaker P, Barroso I, Deloukas P, 
Mathew CG, Blackwell JM, Brown MA, Corvin AP, McCarthy MI, Spencer CC, Bramon E, Corvin AP, O'Donovan MC, Stefansson K, Scolnick E, Purcell S, McCarroll SA, Sklar P, Hultman CM, Sullivan PF; Multicenter Genetic Studies of Schizophrenia ConsortiumPsychosis Endophenotypes International Consortium, Wellcome Trust Case Control Consortium 2. Genome-wide association analysis identifies 13 new risk loci for schizophrenia. Nat Genet 2013;45:1150-9.

37 Schizophrenia Working Group of the Psychiatric Genomics Consortium. Biological insights from 108 schizophrenia-associated genetic loci. Nature 2014:511:421-7.

38 Malhotra AK, Correll CU, Chowdhury NI, Müller DJ, Gregersen PK, Lee AT, Tiwari AK, Kane JM, Fleischhacker WW, Kahn RS, Ophoff RA, Meltzer HY, Lencz T, Kennedy JL. Association between common variants near the melanocortin 4 receptor gene and severe antipsychotic drug-induced weight gain. Arch Gen Psychiatry 2012;69:904-12.

39 Owen MJ, Craddock N, O'Donovan MC. Suggestion of roles for both common and rare risk variants in genome-wide studies of schizophrenia. Arch Gen Psychiatry 2010;67:667-73.

40 Fromer M, Pocklington AJ, Kavanagh DH, Williams HJ, Dwyer S, Gormley P, Georgieva L, Rees E, Palta P, Ruderfer DM, Carrera N, Humphreys I, Johnson JS, Roussos P, Barker DD, Banks E, Milanova V, Grant SG, Hannon E, Rose SA, Chambert K, Mahajan M, Scolnick EM, Moran JL, Kirov G, Palotie A, McCarroll SA, Holmans P, Sklar P, Owen MJ Purcell SM, O'Donovan MC. De novo mutations in schizophrenia implicate synaptic networks. Nature 2014:506:179-84.

41 Niklasson L, Rasmussen P, Oskarsdóttir S, Gillberg C. Autism, ADHD, mental retardation and behavior problems in 100 individuals with 22q11 deletion syndrome. Res Dev Disabil 2009:30:763-73.

42 Owen MJ, Rees E, Kirov G, Sanders A, Walters JT, Chambert KD, Shi J, Szatkiewicz J, O'Dushlaine C, Richards AL, Green EK, Jones I, Davies G, Legge SE, Moran JL, Pato C, Pato M, Genovese G, Levinson D, Duan J, Moy W, Göring HH, Morris D, Cormican P, Kendler KS, O'Neill FA, Riley B, Gill M, Corvin A, Craddock N, Sklar P, Hultman C, Sullivan PF, Gejman PV, McCarroll SA, O'Donovan MC, Owen MJ. Wellcome Trust Case Control Consortium. Evidence that duplications of 22q11.2 protect against schizophrenia. Mol Psychiatry 2014;19:37-40

43 Wright J. Genetics: unravelling complexity. Nature 2014;508:S6-7.

44 Atladóttir HO, Thorsen P, Østergaard L, Schendel DE, Lemcke S, Abdallah M, Parner ET. Maternal infection requiring hospitalization during pregnancy and autism spectrum disorders. J Autism Dev Disord 2010;40:1423-30.

45 Brown AS. Epidemiologic studies of exposure to prenatal infection and risk of schizophrenia and autism. Dev Neurobiol 2012:72:1272-6.

46 Khandaker GM, Zimbron J, Lewis G, Jones PB, infection Pmaternal. Prenatal maternal infection, neurodevelopment and adult schizophrenia: a systematic review of population-based studies. Psychol Med 2013;43:239-57.

47 Khashan AS, Abel KM, McNamee R, Pedersen MG, Webb RT, Baker PN, Kenny LC, Mortensen PB. Higher risk of offspring schizophrenia following antenatal maternal exposure to severe adverse life events. Arch Gen Psychiatry 2008;65:146-52.

48 Ramocki MB, Peters SU, Tavyev YJ, Zhang F, Carvalho CM, Schaaf CP, Richman $R$, Fang P, Glaze DG, Lupski JR, Zoghbi HY. Autism and other neuropsychiatric symptoms are prevalent in individuals with $M e C P 2$ duplication syndrome. Ann Neurol 2009;66:771-82.

49 Budimirovic DB, Kaufmann WE. What can we learn about autism from studying fragile X syndrome? Dev Neurosci 2011;33:379-94.

50 Napoli I, Mercaldo V, Boyl PP, Eleuteri B, Zalfa F, De Rubeis S, Di Marino D, Mohr E, Massimi M, Falconi M, Witke W, Costa-Mattioli M, Sonenberg N, Achsel T, Bagni C. The fragile $X$ syndrome protein represses activity-dependent translation through CYFIP1, a new 4E-BP. Cell 2008;134:1042-54.

51 Barbosa AC, Kim M-S, Ertunc M, Adachi M, Nelson ED, McAnally J, Richardson JA, Kavalali ET, Monteggia LM, Bassel-Duby R, Olson EN. MEF2C, a transcription factor that facilitates learning and memory by negative regulation of synapse numbers and function. Proc Natl Acad Sci 2008;105:9391-6.

52 O'Roak BJ, Vives L, Fu W, Egertson JD, Stanaway IB, Phelps IG, Carvill G, Kumar A, Lee C, Ankenman K, Munson J, Hiatt JB, Turner EH, Levy R, O'Day DR, Krumm N, Coe BP, Martin BK, Borenstein E, Nickerson DA, Mefford HC, Doherty D, Akey JM, Bernier R, Eichler EE, Shendure J. Multiplex targeted sequencing identifies recurrently mutated genes in autism spectrum disorders. Science 2012;338:1619-22.

53 Bernier R, Golzio C, Xiong B, Stessman HA, Coe BP, Penn O, Witherspoon K, Gerdts J, Baker C, Vulto-van Silfhout AT, Schuurs-Hoeijmakers JH, Fichera M, Bosco P, Buono S, Alberti A, Failla P, Peeters H, Steyaert J, Vissers LE, Francescatto L, Mefford HC, Rosenfeld JA, Bakken T, O'Roak BJ, Pawlus M, Moon R, Shendure J, Amaral DG, Lein E, Rankin J, Romano C, de Vries BB, Katsanis N, Eichler EE. Disruptive CHD8 mutations define a subtype of autism early in development. Cell 2014;158:263-76.

54 Chenn A, Walsh CA. Regulation of cerebral cortical size by control of cell cycle exit in neural precursors. Science 2002:297:365-9.

55 Singh T, Kurki MI, Curtis D, Purcell SM, Crooks L, McRae J, Suvisaari J, Chheda H, Blackwood D, Breen G, Pietiläinen O, Gerety SS, Ayub M, Blyth M, Cole T, Collier D, Coomber EL, Craddock N, Daly MJ, Danesh J, DiForti M, Foster A, Freimer NB, Geschwind D, Johnstone M, Joss S, Kirov G, Körkkö J, Kuismin O, Holmans P, Hultman CM, lyegbe C, Lönnqvist J, Männikkö M, McCarroll SA, McGuffin P, McIntosh AM, McQuillin A, Moilanen JS, Moore C, Murray RM, Newbury-Ecob R, Ouwehand W, Paunio T, Prigmore E, Rees E, Roberts D, Sambrook J, Sklar P, St Clair D, Veijola J, Walters JT, Williams H, Sullivan PF, Hurles ME, O'Donovan MC, Palotie A, Owen
MJ, Barrett JC. Swedish Schizophrenia Study, INTERVAL Study, DDD Study, UK10 $\mathrm{K}$ Consortium. Rare loss-of-function variants in SETD1A are associated with schizophrenia and developmental disorders. Nat Neurosci 2016;19:571-7.

56 Flint J. Rare genetic variants and schizophrenia. Nat Neurosci 2016:19:525-7.

57 Neale BM, Kou Y, Liu L, Ma'ayan A, Samocha KE, Sabo A, Lin CF, Stevens C, Wang LS, Makarov V, Polak P, Yoon S, Maguire J, Crawford EL, Campbell NG, Geller ET, Valladares O, Schafer C, Liu H, Zhao T, Cai G, Lihm J, Dannenfelser R, Jabado O, Peralta Z, Nagaswamy U, Muzny D, Reid JG, Newsham I, Wu Y, Lewis L, Han Y, Voight BF, Lim E, Rossin E, Kirby A, Flannick J, Fromer M, Shakir K, Fennell T, Garimella K, Banks E, Poplin R, Gabriel S, DePristo M, Wimbish JR, Boone BE, Levy SE, Betancur C, Sunyaev S, Boerwinkle E, Buxbaum JD, Cook EH, Devlin B, Gibbs RA, Roeder K, Schellenberg GD, Sutcliffe JS, Daly MJ. Patterns and rates of exonic de novo mutations in autism spectrum disorders. Nature 2012:485:242-5

58 O'Roak BJ, Vives L, Girirajan S, Karakoc E, Krumm N, Coe BP, Levy R, Ko A, Lee C, Smith JD, Turner EH, Stanaway IB, Vernot B, Malig M, Baker C, Reilly B, Akey JM, Borenstein E, Rieder MJ, Nickerson DA, Bernier R, Shendure J, Eichler EE. Sporadic autism exomes reveal a highly interconnected protein network of de novo mutations. Nature 2012;485:246-50

59 Leblond CS, Nava C, Polge A, Gauthier J, Huguet G, Lumbroso S, Giuliano F, Stordeur C, Depienne C, Mouzat K, Pinto D, Howe J, Lemière N, Durand CM, Guibert J, Ey E, Toro R, Peyre H, Mathieu A, Amsellem F, Rastam M, Gillberg IC, Rappold GA, Holt R, Monaco AP, Maestrini E, Galan P, Heron D, Jacquette A, Afenjar A, Rastetter A, Brice $A$, Devillard F, Assouline B, Laffargue F, Lespinasse J, Chiesa J, Rivier F, Bonneau D, Regnault B, Zelenika D, Delepine M, Lathrop M, Sanlaville D, Schluth-Bolard C, Edery P, Perrin L, Tabet AC, Schmeisser MJ, Boeckers TM, Coleman M, Sato D, Szatmari P, Scherer SW, Rouleau GA, Betancur C, Leboyer M, Gillberg C, Delorme R, Bourgeron T. Meta-analysis of SHANK mutations in autism spectrum disorders: a gradient of severity in cognitive impairments. PLoS Genet 2014;10:e1004580.

60 Durand CM, Perroy J, Loll F, Perrais D, Fagni L, Bourgeron T, Montcouquiol M, Sans N. SHANK3 mutations identified in autism lead to modification of dendritic spine morphology via an actin-dependent mechanism. Mol Psychiatry 2012;17:71-84.

61 Hung AY, Futai K, Sala C, Valtschanoff JG, Ryu J, Woodworth MA, Kidd FL, Sung CC, Miyakawa T, Bear MF, Weinberg RJ, Sheng M. Smaller dendritic spines, weaker synaptic transmission, but enhanced spatial learning in mice lacking Shank1. J Neurosci 2008:28:1697-708.

62 Peça J, Feliciano C, Ting JT, Wang W, Wells MF, Venkatraman TN, Lascola CD, Fu Z, Feng G. Shank3 mutant mice display autistic-like behaviours and striatal dysfunction. Nature 2011:472:437-42

63 Schmeisser MJ, Ey E, Wegener S, Bockmann J, Stempel AV, Kuebler A, Janssen A-L, Udvardi PT, Shiban E, Spilker C, Balschun D, Skryabin BV, Dieck Stom, Smalla K-H, Montag D, Leblond CS, Faure P, Torquet N, Le Sourd A-M, Toro R, Grabrucker AM, Shoichet SA, Schmitz D, Kreutz MR, Bourgeron T, Gundelfinger ED, Boeckers TM. Autistic-like behaviours and hyperactivity in mice lacking ProSAP1/Shank2. Nature 2012:486:256-60

64 Silverman JL, Turner SM, Barkan CL, Tolu SS, Saxena R, Hung AY, Sheng M, Crawley JN. Sociability and motor functions in Shank1 mutant mice. Brain Res 2011;1380:120-37

65 Wöhr M, Roullet FI, Hung AY, Sheng M, Crawley JN. Communication impairments in mice lacking Shank1: reduced levels of ultrasonic vocalizations and scent marking behavior. PLoS One 2011;6:e20631.

66 Won H, Lee HR, Gee HY, Mah W, Kim JI, Lee J, Ha S, Chung C, Jung ES, Cho YS, Park SG, Lee JS, Lee K, Kim D, Bae YC, Kaang BK, Lee MG, Kim E. Autistic-like social behaviour in Shank2-mutant mice improved by restoring NMDA receptor function. Nature 2012;486:261-5.

67 Swgotpg C. Biological insights from 108 schizophrenia-associated genetic loci. Nature 2014;511:421-7.

68 Taylor LE, Swerdfeger AL, Eslick GD. Vaccines are not associated with autism: an evidence-based meta-analysis of case-control and cohort studies. Vaccine 2014:32:3623-9.

69 Needleman LA, McAllister AK. The major histocompatibility complex and autism spectrum disorder. Dev Neurobiol 2012:72:1288-301.

70 Mostafa GA, Shehab AA. The link of C4B null allele to autism and to a family history of autoimmunity in Egyptian autistic children. J Neuroimmunol 2010;223:115-9.

71 Warren RP, Singh VK, Cole P, Odell JD, Pingree CB, Warren WL, White E. Increased frequency of the null allele at the complement C $4 \mathrm{~b}$ locus in autism. Clin Exp Immunol 1991;83:438-40.

72 Sanders SJ, Murtha MT, Gupta AR, Murdoch JD, Raubeson MJ, Willsey AJ, ErcanSencicek AG, DiLullo NM, Parikshak NN, Stein JL, Walker MF, Ober GT, Teran NA, Song Y, El-Fishawy P, Murtha RC, Choi M, Overton JD, Bjornson RD, Carriero NJ, Meyer KA, Bilguvar K, Mane SM, Sestan N, Lifton RP, Günel M, Roeder K, Geschwind DH, Devlin $B$, State MW. De novo mutations revealed by whole-exome sequencing are strongly associated with autism. Nature 2012:485:237-41.

73 O'Roak BJ, Deriziotis P, Lee C, Vives L, Schwartz JJ, Girirajan S, Karakoc E, MacKenzie AP, Ng SB, Baker C, Rieder MJ, Nickerson DA, Bernier R, Fisher SE, Shendure J, Eichler $\mathrm{EE}$. Exome sequencing in sporadic autism spectrum disorders identifies severe de novo mutations. Nat Genet 2011;43:585-9.

74 Bhat SS, Ladd S, Grass F, Spence JE, Brasington CK, Simensen RJ, Schwartz CE, Dupont BR, Stevenson RE, Srivastava AK. Disruption of the IL1RAPL1 gene associated with a 
pericentromeric inversion of the $X$ chromosome in a patient with mental retardation and autism. Clin Genet 2008;73:94-6.

75 Takahashi H, Craig AM. Protein tyrosine phosphatases PTPdelta, PTPsigma, and LAR: presynaptic hubs for synapse organization. Trends Neurosci 2013;36:522-34.

76 Sekar A, Bialas AR, de Rivera H, Davis A, Hammond TR, Kamitaki N, Tooley K, Presumey J, Baum M, Van Doren V, Genovese G, Rose SA, Handsaker RE, Daly MJ, Carroll MC, Stevens B, McCarroll SA; Schizophrenia Working Group of the Psychiatric Genomics Consortium. Schizophrenia risk from complex variation of complement component 4. Nature 2016;530:177-83.

77 Paciorkowski AR, Traylor RN, Rosenfeld JA, Hoover JM, Harris CJ, Winter S, Lacassie Y, Bialer M, Lamb AN, Schultz RA, Berry-Kravis E, Porter BE, Falk M, Venkat A, Vanzo RJ, Cohen JS, Fatemi A, Dobyns WB, Shaffer LG, Ballif BC, Marsh ED. MEF2C haploinsufficiency features consistent hyperkinesis, variable epilepsy, and has a role in dorsal and ventral neuronal developmental pathways. Neurogenetics 2013;14:99-111.

78 Williams SR, Aldred MA, Der Kaloustian VM, Halal F, Gowans G, McLeod DR, Zondag S, Toriello HV, Magenis RE, Elsea SH. Haploinsufficiency of HDAC4 causes brachydactyly mental retardation syndrome, with brachydactyly type $E$, developmental delays, and behavioral problems. Am J Hum Genet 2010;87:219-28.

79 Jiang YH, Yuen RK, Jin X, Wang M, Chen N, Wu X, Ju J, Mei J, Shi Y, He M, Wang G, Liang J, Wang Z, Cao D, Carter MT, Chrysler C, Drmic IE, Howe JL, Lau L, Marshall CR, Merico D, Nalpathamkalam T, Thiruvahindrapuram B, Thompson A, Uddin M, Walker S, Luo J, Anagnostou E, Zwaigenbaum L, Ring RH, Wang J, Lajonchere C, Wang J, Shih A, Szatmari P, Yang H, Dawson G, Li Y, Scherer SW. Detection of clinically relevant genetic variants in autism spectrum disorder by whole-genome sequencing. Am J Hum Genet 2013:93:249-63.

80 Loe-Mie Y, Lepagnol-Bestel AM, Maussion G, Doron-Faigenboim A, Imbeaud S, Delacroix H, Aggerbeck L, Pupko T, Gorwood P, Simonneau M, Moalic JM. SMARCA2 and other genome-wide supported schizophrenia-associated genes: regulation by REST/NRSF, network organization and primate-specific evolution. Hum Mol Genet 2010;19:2841-57.

81 Deriziotis P, O'Roak BJ, Graham SA, Estruch SB, Dimitropoulou D, Bernier RA, Gerdts J, Shendure J, Eichler EE, Fisher SE. De novo TBR1 mutations in sporadic autism disrupt protein functions. Nat Commun 2014;5:4954.

82 Neves-Pereira M, Müller B, Massie D, Williams JH, O'Brien PC, Hughes A, Shen SB, Clair DS, Miedzybrodzka Z. Deregulation of EIF4E: a novel mechanism for autism. J Med Genet 2009;46:759-65.

83 Takata A, Xu B, Ionita-Laza I, Roos JL, Gogos JA, Karayiorgou M. Loss-of-function variants in schizophrenia risk and SETD1A as a candidate susceptibility gene. Neuron 2014:82:773-80.

84 Gulsuner S, Walsh T, Watts AC, Lee MK, Thornton AM, Casadei S, Rippey C, Shahin H, Nimgaonkar VL, Go RC, Savage RM, Swerdlow NR, Gur RE, Braff DL, King MC,
McClellan JM; Consortium on the Genetics of Schizophrenia (COGS)PAARTNERS Study Group. Spatial and temporal mapping of de novo mutations in schizophrenia to a fetal prefrontal cortical network. Cell 2013;154:518-29.

85 Xu B, lonita-Laza I, Roos JL, Boone B, Woodrick S, Sun Y, Levy S, Gogos JA Karayiorgou M. De novo gene mutations highlight patterns of genetic and neural complexity in schizophrenia. Nat Genet 2012;44:1365-9.

86 Mbarek O, Marouillat S, Martineau J, Barthélémy C, Müh JP, Andres C. Association study of the NF1 gene and autistic disorder. Am J Med Genet 1999:88:729-32.

87 Goffin A, Hoefsloot LH, Bosgoed E, Swillen A, Fryns JP. PTEN mutation in a family with Cowden syndrome and autism. Am J Med Genet 2001;105:521-4.

88 Serajee FJ. Association of INPP1, PIK3CG, and TSC2 gene variants with autistic disorder: implications for phosphatidylinositol signalling in autism. J Med Genet 2003:40: e119.

89 Iossifov I, Ronemus M, Levy D, Wang Z, Hakker I, Rosenbaum J, Yamrom B, Lee YH, Narzisi G, Leotta A, Kendall J, Grabowska E, Ma B, Marks S, Rodgers L, Stepansky A, Troge J, Andrews P, Bekritsky M, Pradhan K, Ghiban E, Kramer M, Parla J, Demeter R, Fulton LL, Fulton RS, Magrini VJ, Ye K, Darnell JC, Darnell RB, Mardis ER, Wilson RK, Schatz MC, McCombie WR, Wigler M. De novo gene disruptions in children on the autistic spectrum. Neuron 2012;74:285-99.

90 Egawa J, Watanabe $Y$, Wang C, Inoue E, Sugimoto A, Sugiyama T, Igeta H, Nunokawa A, Shibuya M, Kushima I, Orime N, Hayashi T, Okada T, Uno Y, Ozaki N, Someya T. Novel rare missense variations and risk of autism spectrum disorder: whole-exome sequencing in two families with affected siblings and a two-stage follow-up study in a Japanese population. PLoS One 2015:10:e0119413.

91 Ramos PS, Sajuthi S, Langefeld CD, Walker SJ. Immune function genes CD99L2, JARID2 and TPO show association with autism spectrum disorder. Mol Autism 2012;3:4.

92 Peng $Y_{\text {, Huentelman } M}$, Smith C, Qiu S. MET receptor tyrosine kinase as an autism genetic risk factor. Int Rev Neurobiol 2013;113:135-65.

93 Careaga M, Ashwood P. Autism spectrum disorders: from immunity to behavior Methods Mol Biol 2012;934:219-40.

94 Torres AR, Sweeten TL, Johnson RC, Odell D, Westover JB, Bray-Ward P, Ward DC, Davies CJ, Thomas AJ, Croen LA, Benson M. Common genetic variants found in HLA and KIR immune genes in autism spectrum disorder. Front Neurosci 2016;10:463.

95 Chien YL, Wu YY, Chen CH, Gau SS, Huang YS, Chien WH, Hu FC, Chao YL, Yy W, Fc H. Association of HLA-DRB1 alleles and neuropsychological function in autism. Psychiatr Genet 2012:22:46-9.

96 Piton A, Michaud JL, Peng H, Aradhya S, Gauthier J, Mottron L, Champagne N, Lafrenière RG, Hamdan FF, Joober R, Fombonne E, Marineau C, Cossette P, Dubé MP, Haghighi P, Drapeau P, Barker PA, Carbonetto S, Rouleau GA; S2D team. Mutations in the calcium-related gene IL1RAPL1 are associated with autism. Hum Mol Genet 2008:17:3965-74. 